\title{
Evaluation of Biosorptive Capacity of Banana (Musa paradisiaca) Stalk for Lead(II) Removal from Aqueous Solution
}

\author{
Oladipupo 0. Ogunleye*, Mary A. Ajala, Samuel E. Agarry \\ Department of Chemical Engineering, Ladoke Akintola University of Technology, Ogbomoso, Nigeria \\ Email: ${ }^{*}$ ooogunleye@yahoo.com
}

Received 27 August 2014; revised 21 September 2014; accepted 11 October 2014

Copyright (C) 2014 by authors and Scientific Research Publishing Inc.

This work is licensed under the Creative Commons Attribution International License (CC BY). http://creativecommons.org/licenses/by/4.0/

(c) (i) 0pen Access

\section{Abstract}

Raw Banana Stalk (RBS), Acid Activated Banana Stalk (AABS) and Base Activated Banana Stalk (BABS) prepared from banana stalk were used as biosorbents to remove Lead(II) from aqueous solution. The biosorbents were characterised using proximate analysis and Fourier Transform Infrared (FTIR) spectroscopy. $\mathrm{Pb}$ (II) of $1000 \mathrm{mg} / \mathrm{L}$ concentration was prepared from $\mathrm{Pb}\left(\mathrm{NO}_{3}\right)_{2}$ salt and other concentrations were obtained from this stock through serial dilution. Effects of adsorbent dose, temperature, initial metal concentration, contact time and $\mathrm{pH}$ on the percentage $\mathrm{Pb}$ (II) removal were evaluated. The $\mathrm{Pb}$ (II) concentrations in the solutions were analysed using Atomic Absorption Spectrophotometer. Kinetic, isotherm and thermodynamic parameters were determined. FTIR spectroscopy showed that RBS, AABS and BABS are rich in carboxyl, hydroxyl and phenolic functional groups. At an equilibrium time of 180 minutes, the percentage $\mathrm{Pb}$ (II) removal was $63.97 \%, 96.13 \%$ and $66.90 \%$ for RBS, AABS and BABS, respectively. Pseudo-second order kinetics best described the process with $R^{2}(0.95,0.98,0.97)$ for RBS, AABS and BABS, respectively. Langmuir isotherm (AABS) has the maximum adsorption capacity $\left(q_{\max }\right)$ of $13.53 \mathrm{mg} / \mathrm{g}$ and $R^{2}$ (0.99). Thermodynamic parameters obtained were $\Delta G^{0}(-18.75 \mathrm{~kJ} / \mathrm{mol}), \Delta H^{0}(12.63 \mathrm{~kJ} / \mathrm{mol})$, $\Delta S^{0}(0.05 \mathrm{~kJ} / \mathrm{mol} \cdot \mathrm{K})$ and $E_{a} \quad(4.37 \mathrm{~kJ} / \mathrm{mol})$. Banana stalk has viable characteristics for preparing biosorbents. Acid activated banana biosorbent is more efficient for removal of lead ions from its aqueous solution.

\section{Keywords}

Biosorption, Isotherm, Banana Stalk, Kinetics, Lead(II)

\footnotetext{
${ }^{*}$ Corresponding author.
} 


\section{Introduction}

Lead is one of the heavy metals that are often found in industrial wastewater and its discharge into the environment poses serious threat due to its toxicity to aquatic and terrestrial lives [1] [2]. It is a group IV element on the periodic table which is remarkably highly resistant to corrosion in most acid and naturally occur as element buried in the earth crust in insoluble and biologically inoffensive forms [3]. Enhanced industrialization such as manufacturing of storage batteries, television tube, printing, paints, pigments, photographic materials, gasoline additives, matches and explosives brought about lead bearing wastewater [4]-[7].

Exposure to Lead is widely recognized as a major risk factor for several human diseases once it goes beyond the World Health Organisation (WHO) maximum permissible limit $\left(3-10 \mu \mathrm{g} \cdot \mathrm{L}^{-1}\right)$ in drinking water [8]-[12]. It forms complexes with oxo-groups in enzymes to affect virtually all steps in the process of haemoglobin synthesis and porphyrin metabolism [13]. Other problems associated with toxic levels of lead exposure are encephalopathy, seizures and mental retardation, anemia and nephropathy [14] [15]. Hence, lead must be removed as much as possible from industrial effluents to prevent environmental hazard from its discharge.

Adsorption technology has been widely preferred to other traditional methods such as coagulation, flocculation, filtration, ozonation or sedimentation in the removal of pollutants from wastewater [16]-[18]. In this technology, activated carbons are commonly used adsorbent due to their high adsorption capacity, a result of their high surface area and surface reactivity but their regeneration is, however, difficult and expensive [19] [20].

Quest for effective and economical technologies have brought about biosorption. It is based on metal binding capacities of various biological materials mainly composed of cellulose, hemicelluloses and lignin that make them effective adsorbents for a wide range of pollutants due to the presence of functional groups such as hydroxyl, carboxyl, methoxyl and phenols [21]-[25]. Recent studies have shown that heavy metals can be removed using plant materials such as empty palm oil fruit bunch [26], sour soup seeds [27], modified cassava fibre [28], coconut shell [29], duck weed [30], sago waste [31], African spinach stalk [32], palm fruit fibre [33], hop [34], orange peels [35]-[37] and spent tea leaves [18] [38].

Banana Stalks (BS) are generated in large amount as waste product after the consumption of banana and these constitute environmental menace due to the fact that they are left to decompose being of non-economic importance [39]. However, BS is a rich lignocellulosic agricultural waste whose previous application has been limited to the production of activated carbon for malachite green dye removal [40] and not yet applied to $\mathrm{Pb}(\mathrm{II})$ removal [41]-[48]. The present study investigated the adsorptive capacity of BS as a low-cost adsorbent for the biosorption of Lead(II) from aqueous solution. The effects of physical parameters such as initial concentration, $\mathrm{pH}$, and temperature and biosorbent dosage on the biosorption process have been investigated. In addition, the biosorption equilibrium isotherms, kinetics and thermodynamic parameters have been determined.

\section{Materials and Method}

\subsection{Preparation and Characterization of Adsorbent}

Banana Stalks were first sundried, cut into small pieces and washed with distilled water to remove dirt particles. $\mathrm{BS}$ pieces were then dried in the oven at $100^{\circ} \mathrm{C}$ for 24 hours to constant weight before being grounded and screened to 300 - $425 \mu \mathrm{m}$ mesh particle size. It was then stored as Raw Banana Stalk (RBS). RBS of $200 \mathrm{~g}$ was soaked with $1 \mathrm{M} \mathrm{H}_{3} \mathrm{PO}_{4}$ in ratio 1:1, kept in the oven for 24 hours at $80^{\circ} \mathrm{C}$ for activation and stored as Acid Activated Banana Stalk (AABS). Similarly, Base Activated Banana Stalk (BABS) was prepared by soaking another $200 \mathrm{~g}$ of the RBS in $0.1 \mathrm{M} \mathrm{KOH}$ for 24 hours at $80^{\circ} \mathrm{C}$ in an oven and stored as BABS. The Proximate analysis of the biosorbents was carried out to know the percentage compositions of its constituents. Fourier Transform Infrared (FTIR) spectroscopic analysis was performed on RBS, AABS and BABS using FTIR spectroscope (FTIR-2000, Perkin-Elmer). The spectra were measured from 4000 to $400 \mathrm{~cm}^{-1}$.

\subsection{Preparation of Simulated Wastewater}

Simulated wastewater samples containing $\mathrm{Pb}(\mathrm{II})$ was prepared from $\mathrm{Pb}\left(\mathrm{NO}_{3}\right)_{2}$ of $1000 \mathrm{mg} \cdot \mathrm{L}^{-1}$ stock solutions. Reagents used were of analytical grade and deionized water was used in solution preparation. Other concentrations (20 - $100 \mathrm{mg} / \mathrm{L}$ ) were obtained from this stock solution by serial dilution. Fresh dilutions were used for each experiment. The concentration of $\mathrm{Pb}(\mathrm{II})$ in simulated wastewater was analysed by Atomic Absorption Spectrophotometer (model PyeUnicam SP-9 Cambridge, UK). 


\subsection{Batch Biosorption Equilibrium Studies}

Batch equilibrium tests were carried out on the adsorption of $\mathrm{Pb}(\mathrm{II})$ on RBS. The effect of initial metal ion concentration, contact time, temperature, solution $\mathrm{pH}$ and adsorbent dose were investigated. Sample solutions were withdrawn at time interval and equilibrium to determine residual concentrations. Solutions were filtered prior to analysis in order to minimise the interference of the RBS. For equilibrium studies, the experiment was carried out for 360 minutes to ensure that equilibrium was reached. The linear Beer-Lambert relationship between absorbance and concentration with the calibration curve was established by plotting the graph of absorbance versus concentration of the lead solution. The concentration of lead solution before and after adsorption was determined using an Atomic Absorption Spectrophotometer (model PyeUnicam SP-9 Cambridge, UK). This experiment was done in turns for AABS and BABS.

The adsorbed phase concentration ( $q_{t}$, in $\mathrm{mg} / \mathrm{g}$ ) at time $(t)$ was calculated using Equation (1)

$$
q_{t}=\frac{\left(C_{o}-C_{t}\right) V}{m}
$$

where, $C_{o}$ and $C_{t}$ are the initial and the final lead concentration $(\mathrm{mg} / \mathrm{L})$, respectively; $V$ is the water sample volume (L); and $m$ is the mass of adsorbent used (g).

The biosorption at equilibrium, $q_{e}$ (mg/g), was calculated according to Equation (2)

$$
q_{e}=\frac{\left(C_{o}-C_{e}\right) V}{m}
$$

where, $C_{o}$ and $C_{e}$ are the initial and the final (equilibrium) lead concentration (mg/L) respectively; $V$ is the water sample volume (L); and $m$ is the mass of adsorbent used (g). The percentage of lead ion removal was calculated using Equation (3):

$$
\text { Removal }(\%)=\frac{C_{o}-C_{t}}{C_{o}} \times 100 \%
$$

\subsection{Effects of Adsorption Conditions}

RBS of $1 \mathrm{~g}$ was measured into a $125 \mathrm{ml}$ Erlenmeyer flask with $100 \mathrm{ml}$ of $100 \mathrm{mg} / \mathrm{l}$ of $\mathrm{Pb}$ (II) solution with pH of 7 monitored using a pH meter (model CD70 WPA) and controlled with $0.1 \mathrm{M} \mathrm{NaOH}$ and $0.1 \mathrm{M} \mathrm{HCl}$. The flask was agitated at $30^{\circ} \mathrm{C}$ at a constant $125 \mathrm{rpm}$ using the Thermostatic water bath shaker, the sorption experiment carried out for sufficient time of 360 minutes. The supernatant was filtered using Watman Filter Paper and Lead(II) concentration was analysed using Atomic Absorption Spectrophotometer (AAS). The effect of contact time (30, 60, 90, 120, 150, 180, 210, 240, 300, 360 minutes), biosorbent dose (0.2, 0.4, 0.6, 0.8, 1.0, 1.5 and 2.0 g), initial metal ion concentration (20, 40, 60, 80, 100 and $120 \mathrm{mg} / \mathrm{L}), \mathrm{pH}(4,6$ and 8) and temperature (30, 40 and $50^{\circ} \mathrm{C}$ ) were evaluated during the study. During the experiment, the particular parameter considered was varied while the other four were kept constant variously for RBS, BABS and AABS biosorbents.

\section{Results and Discussion}

\subsection{Characterisation of Biosorbent}

The result of proximate analysis carried out on the biosorbent samples are as presented in Table 1. It revealed that the AABS, BABS and RBS are rich in crude fibre of $67.69 \%, 62.07 \%$ and 58.47\%, respectively. This rich crude fibre comprise of lignin, cellulose and hemicellulose content. Lignin is a compound rich with functional groups, such as carbonyl, ether and hydroxyl [21] [41] and has been used for metals adsorption by some researchers [40] [49]. The implication of this is that the presence of the active site presupposes that banana stalks are good biosorbents. The FTIR spectra characteristics for the three biosorbents are as shown on Table 2 while main spectra are on Figure 1. The analysis revealed that the biosorbents are rich in hydroxyl, carboxyl and the phenolic groups which indicates that RBS, AABS and BABS are viable for the adsorption of $\mathrm{Pb}$ (II) onto the biosorbents. 


\subsection{Effect of Initial Concentration and Contact Time}

The rate of biosorption is a function of the initial concentration and contact time of the sorbate and these makes them important factors for effective biosorption. Figure 2 shows the effect of contact time on $\mathrm{Pb}(\mathrm{II})$ adsorption onto RBS, BABS and AABS. It was found that the adsorption of $\mathrm{Pb}(\mathrm{II})$ by the three banana stalks increased with contact time until equilibrium was reached at around 180 minutes. The biosorption process was rapid initially

Table 1. Proximate analysis of banana stalks.

\begin{tabular}{cccccc}
\hline Sample & Moisture content (\%) & Ash content (\%) & Crude fibre (\%) & Protein (\%) & Carbohydrate (\%) \\
\hline AABS & 10.38 & 5.52 & 67.69 & 6.29 & 10.12 \\
BABS & 10.88 & 5.93 & 62.07 & 7.93 & 13.26 \\
RBS & 12.19 & 7.40 & 58.47 & 8.58 & 14.10 \\
\hline
\end{tabular}

Table 2. FTIR spectra characteristics for RBS, BABS and AABS.

\begin{tabular}{ccccl}
\hline IR peak & \multicolumn{4}{c}{ Band wave number $\left(\mathrm{cm}^{-1}\right)$} \\
& RBS & BABS & AABS & \multicolumn{1}{c}{ Assigned functional group } \\
1 & 3889.63 & 3287.10 & 3327.12 & O-H stretching vibration of alcohol or carbonyl acid \\
2 & 2918.26 & 2920.86 & 2918.94 & C-H stretching vibration of alkane \\
3 & 2184.23 & 2541.21 & 2209.05 & C-H stretching of alkyne \\
4 & 1916.51 & & & C-O stretching vibration of alkene and ketones \\
5 & 1636.18 & 1604.94 & 1628.34 & C-H stretching of alkene \\
6 & 1029.54 & 897.33 & 660.63 & CH bending vibration of C- $\mathrm{H}_{2}$ and C- $\mathrm{H}_{3}$ (finger print region) \\
\hline
\end{tabular}

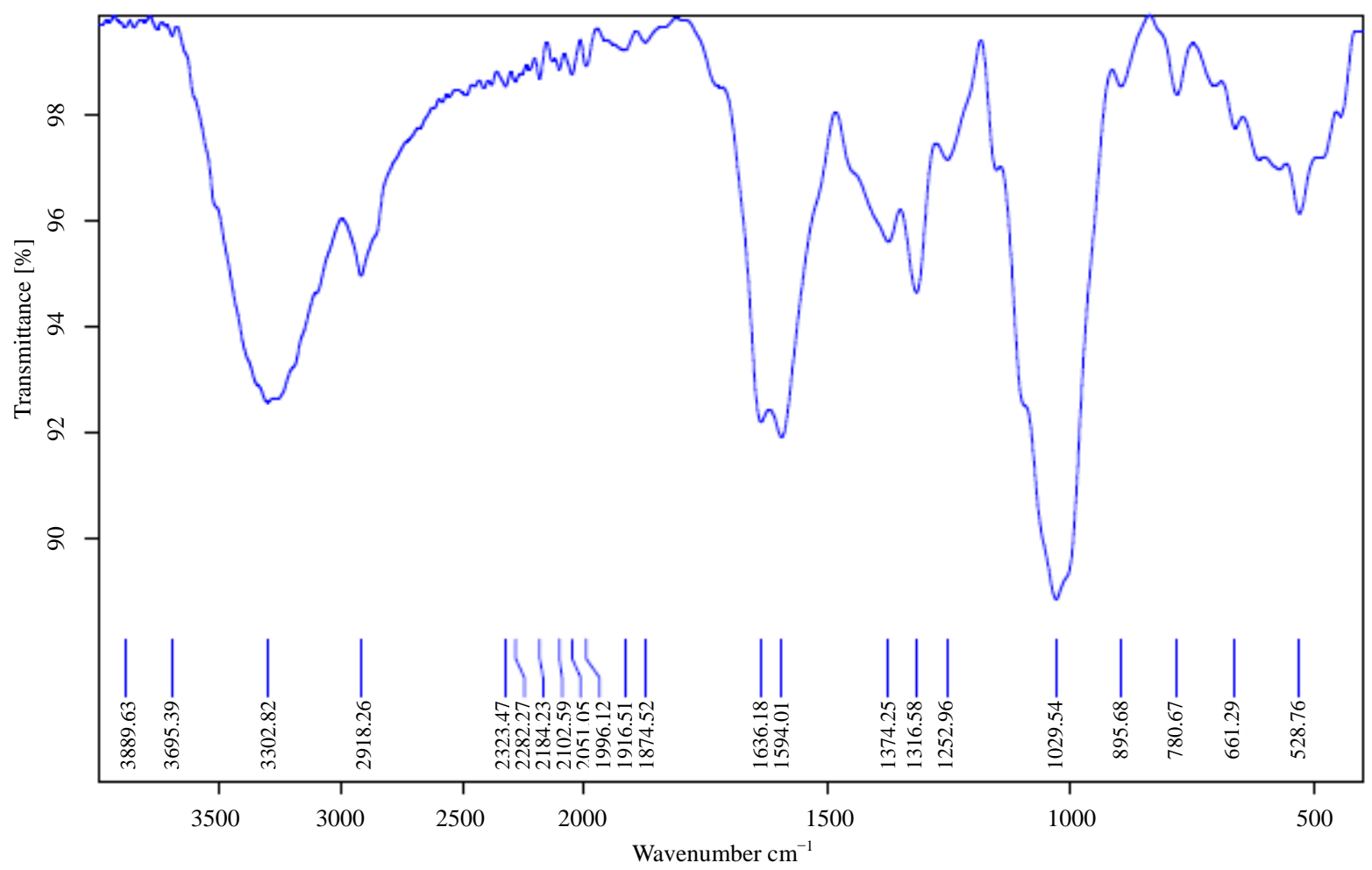

(a) 


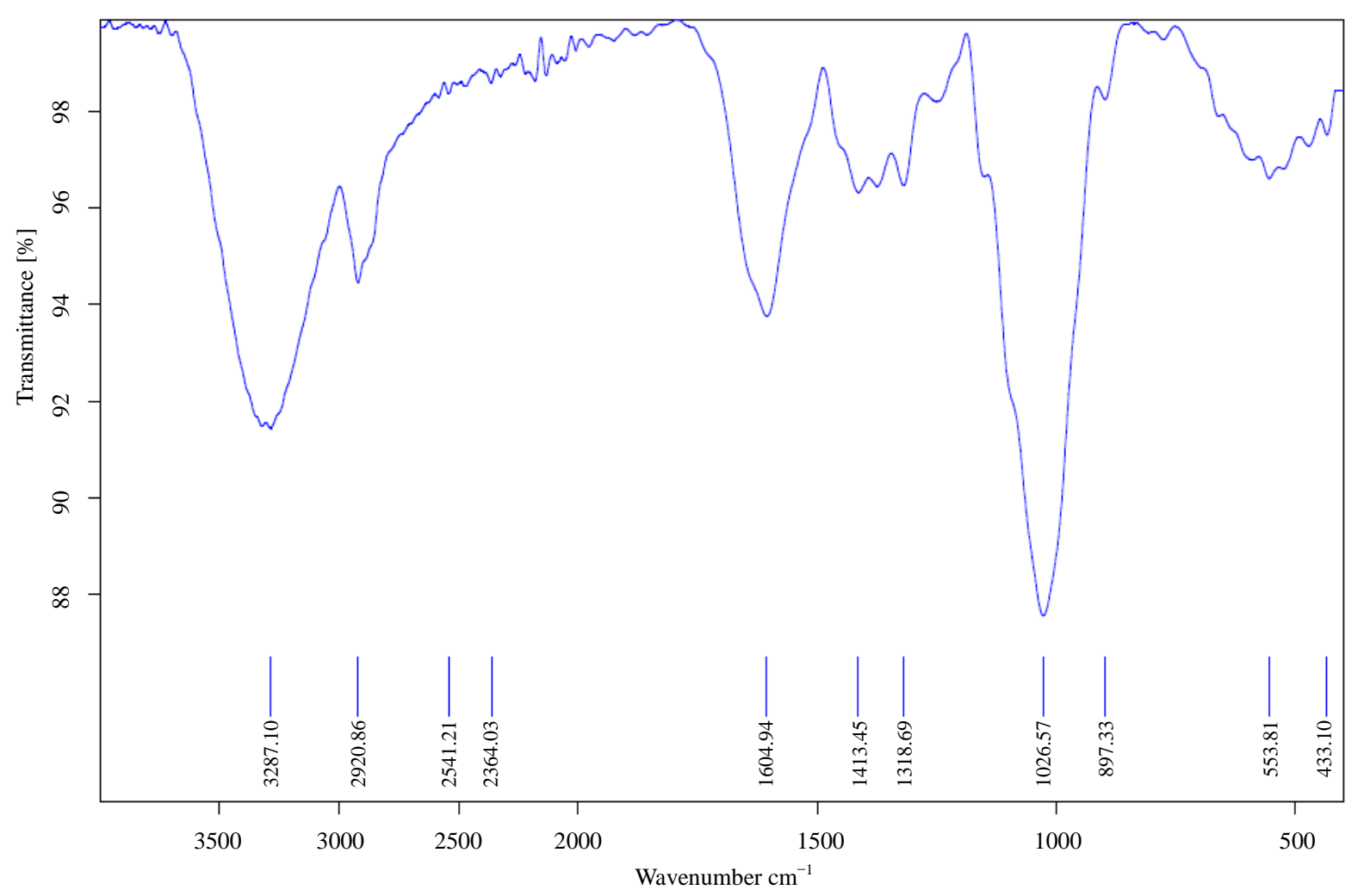

(b)

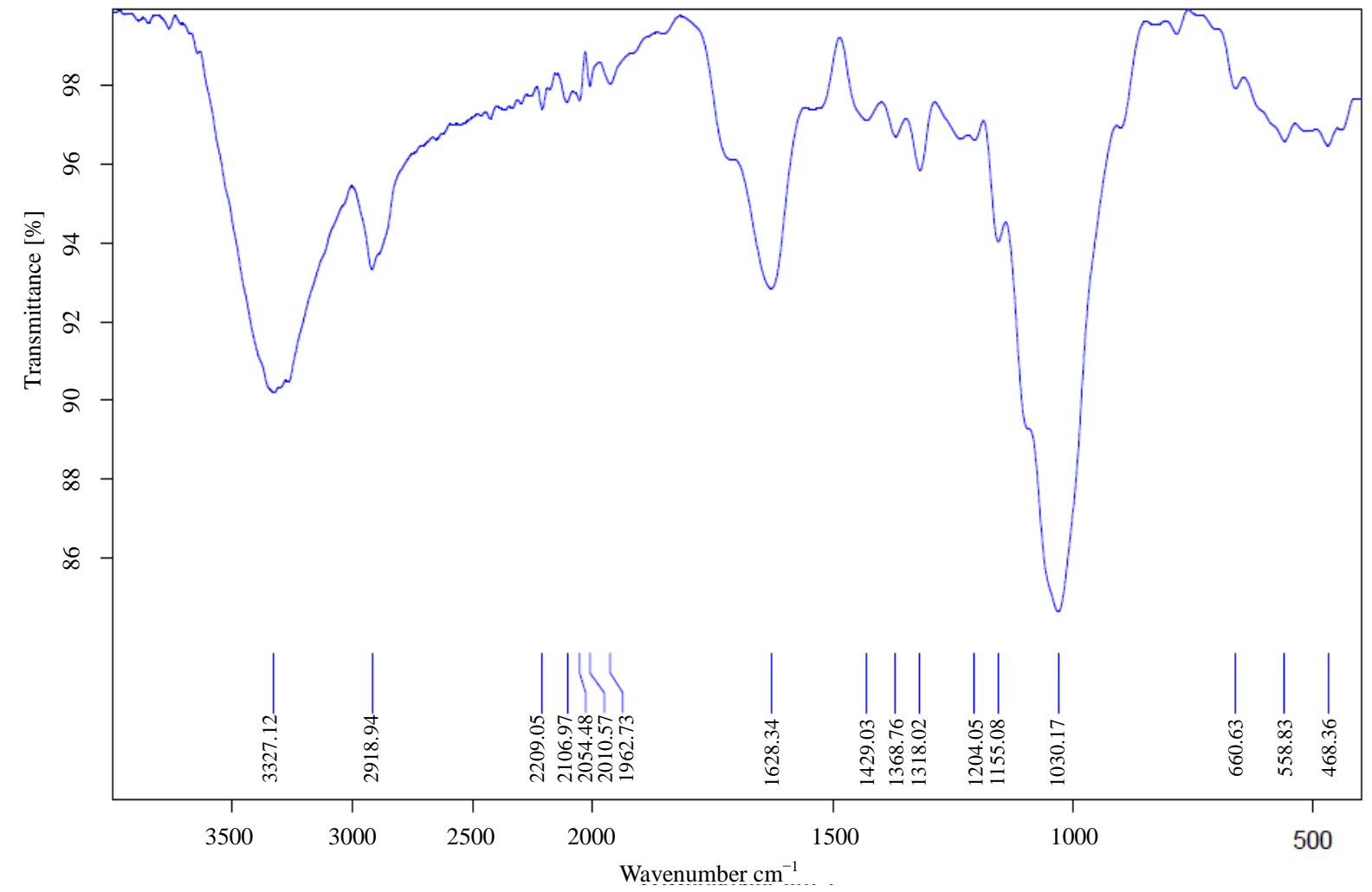

(c)

Figure 1. FTIR Spectroscopy for the biosorbents, (a) RBS; (b) BABS; (c) AABS. 


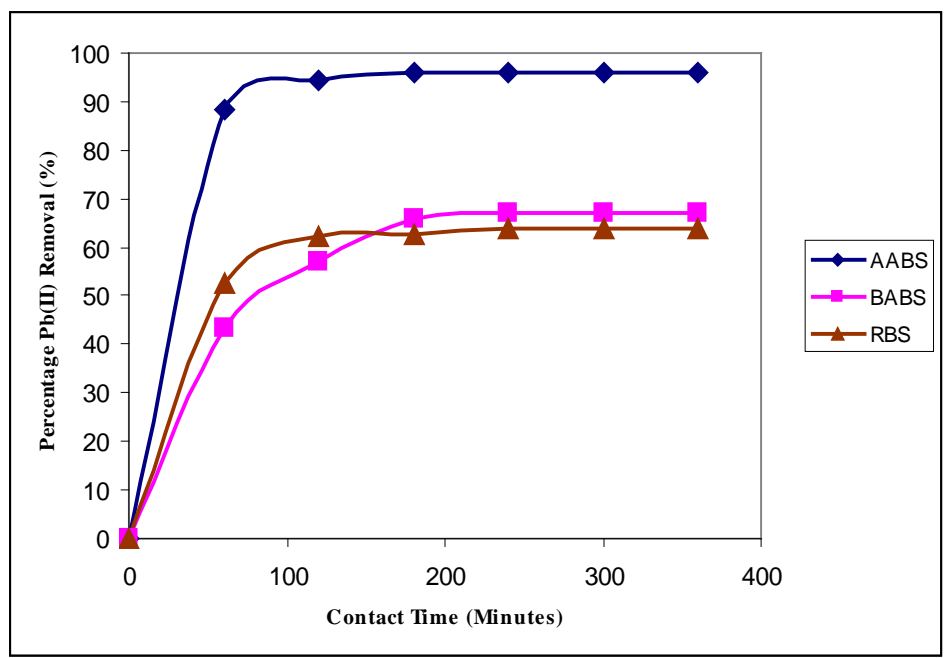

Figure 2. Effect of contact time on the percentage removal of Lead(II).

due to increased availability of active binding site on the biosorbent surface and this is controlled by diffusion process from the bulk to the surface. However, during the last stages, biosorption is likely to be attachmentcontrolled process due to reduction in the available active sites. AABS has $96.00 \%$ removal at equilibrium, followed by BABS (66.90\%) while RBS had the least percentage removal and adsorptive capacity even beyond 180 minutes of $63.9 \%$ and $6.39 \mathrm{mg} \cdot \mathrm{g}^{-1}$, respectively. Figure 3 reveals that, at lower concentrations of $20-40$ $\mathrm{mg} \cdot \mathrm{L}^{-1}$, biosorption was completed at about 60 minutes while at higher concentration, the biosorption process became constant at 180 mins as observed in Figures 3(a)-3(c), respectively. At lower concentrations, all metal ions present in the solution interacted with binding sites and then facilitated about $70.1 \%$ on RBS (Figure 3(a)) 74.6\% on BABS (Figure 3(b)) with 93\% Pb(II) removal on AABS (Figure 3(c)). At higher concentrations between $80-120 \mathrm{mg} \cdot \mathrm{L}^{-1}$, more $\mathrm{Pb}$ (II) is left unabsorbed in the solution due to the saturation of binding sites. This may be due to the increase in the number of ions competing for available binding sites on the three Banana Stalks considered in this study. This result is similar to other researcher findings [18] [50].

\subsection{Effect of Adsorbent Dose}

Varying adsorbent dosage of 0.2 to $2.0 \mathrm{~g}$ were used to test for the effect of adsorbent dose on the biosorption process keeping the initial lead concentration at $100 \mathrm{mg} \cdot \mathrm{L}^{-1}$, while all other parameters were kept constant. It was observed as shown on Figure 4 that, when the adsorbent dose was increased from $0.2 \mathrm{~g}$ to $2.0 \mathrm{~g}$, the percentage adsorption generally increased from $30.2 \%$ to $97.3 \%$, but the amount adsorbed per unit mass of adsorbent decreased considerably. The increase in the adsorption percentage or decrease in unit adsorption with increased dose of the biosorbent is due to the increase in active sites on the adsorbent and thus making easier penetration of the metal ions to the adsorption sites which is in agreement with previous researcher [33]. When the adsorbent added is beyond $0.6 \mathrm{~g}$, the decrease in lead ion adsorption is not very prominent which is perhaps due to the formation of adsorbent agglomerates reducing available surface area and blocking some of the adsorption sites. Maximum adsorption capacity of lead ions was observed with adsorbent dose of $0.6 \mathrm{~g}$ with adsorption capacity of $15.8 \mathrm{mg} \cdot \mathrm{g}^{-1}$ and thereafter, a slow increase in the percentage removal was seen reaching a constant value with respect to adsorbent dosage.

\subsection{Effect of $\mathrm{pH}$}

Surface charges on the adsorbent and degree of ionization of the sorbate are affected by the $\mathrm{pH}$ of the solution and this makes $\mathrm{pH}$ and important factor in adsorptive studies. Figure 5 reveals that, the adsorptive capacity was best at $\mathrm{pH} 8$ with $89 \%$ removal of the lead ion. This is because biosorption is low at strong acidic medium (pH 2 - 4) because the surface charge on the biosorbents is positive, thus, $\mathrm{Pb}(\mathrm{II})$ is not favourable attached because of electrostatic repulsion between the RBS, BABS and AABS surfaces and the positively charged $\mathrm{Pb}(\mathrm{II})$. At higher $\mathrm{pH}$, uptake increased because more metal binding sites could be exposed and carried negative charges, with 


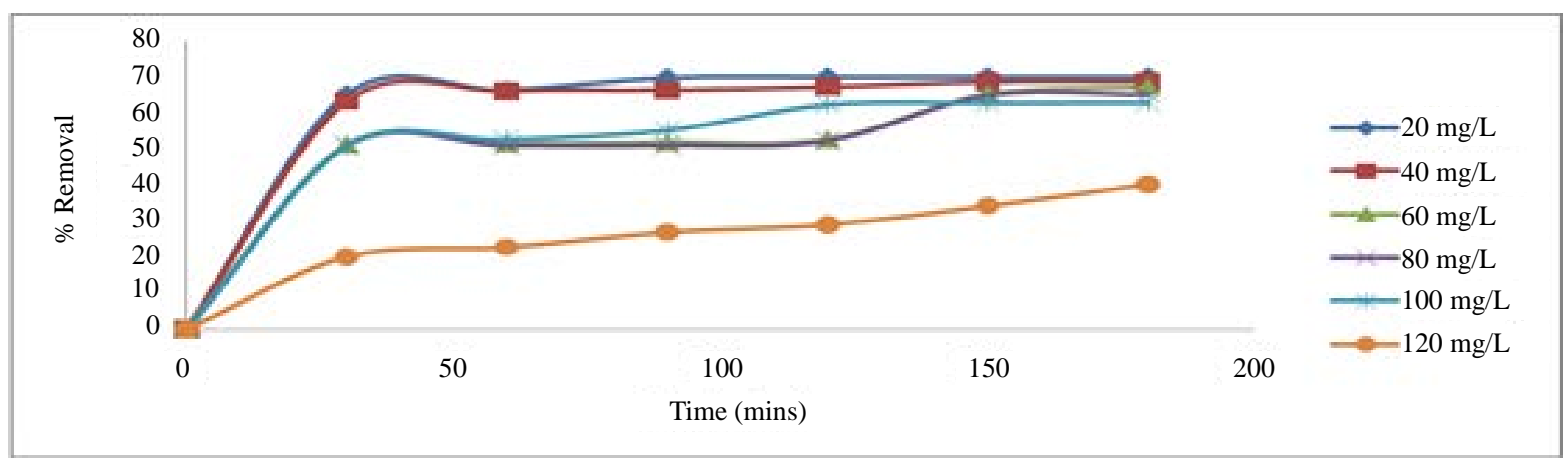

(a)

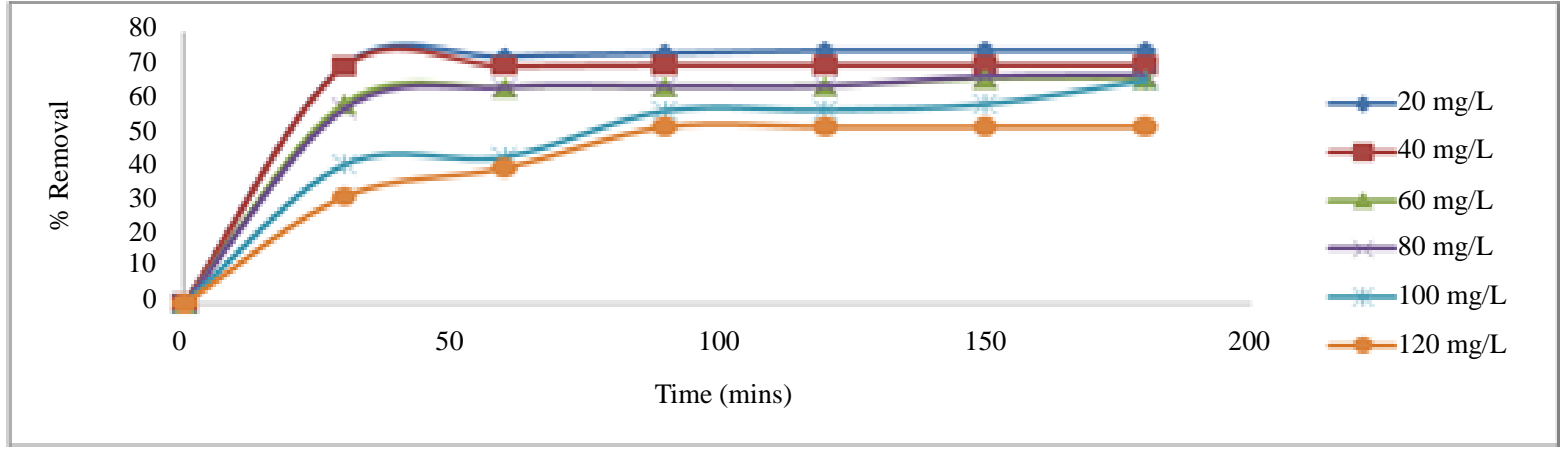

(b)

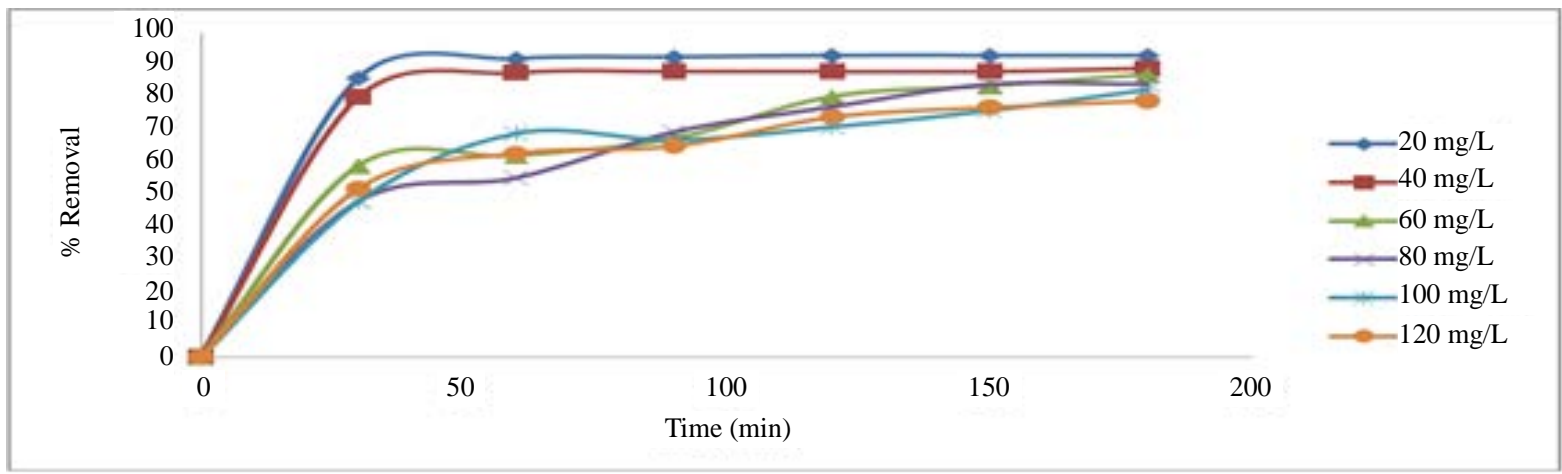

(c)

Figure 3. Effect of different initial lead concentration on the percentage removal of $\mathrm{Pb}(\mathrm{II})$ on Raw banana stalk biosorbent, (a) RBS; (b) BABS; (c) AABS.

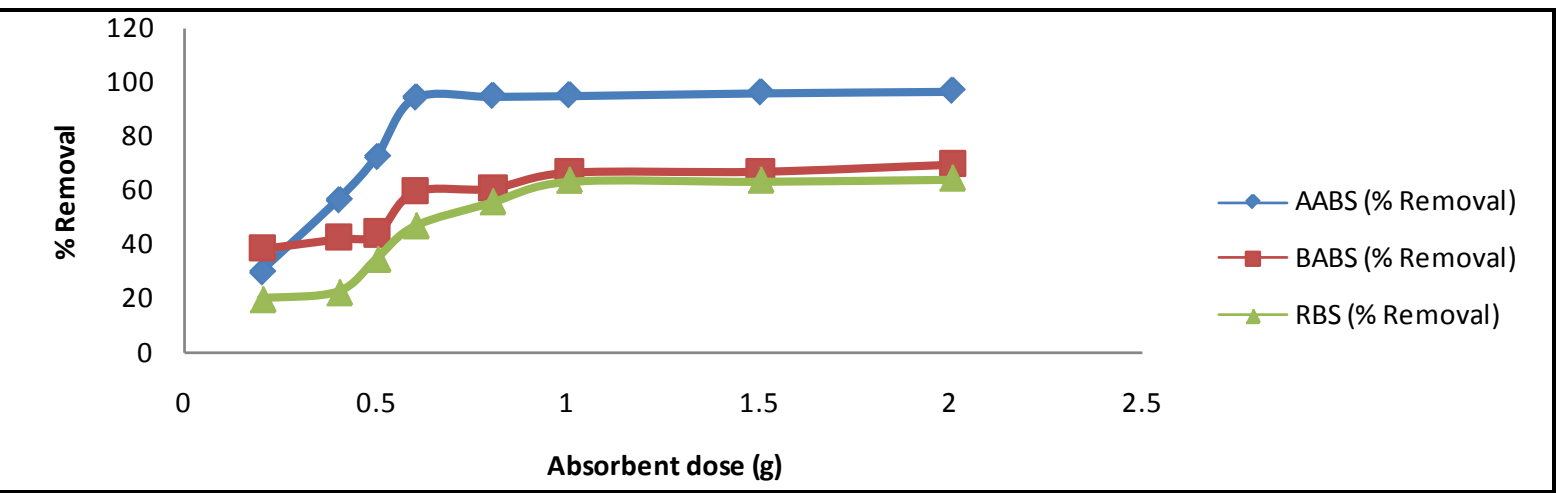

Figure 4. Effect of adsorbent dose on the percentage removal of $\mathrm{Pb}(\mathrm{II})$ removal using different biosorbents. 
subsequent attraction of the positively charged metal ions with the biosorbent surface and this agreed with Bello et al. [40] on the adsorptive features of banana stalk-based activated carbon for malachite green dye removal. Experiments were carried out with the $\mathrm{pH}$ values of up to 8 due to the fact that metal precipitation appeared at higher $\mathrm{pH}$ values and interfered with the accumulation or biosorbent deterioration which was in agreement with the result obtained by Puranik and Paknikar [51].

\subsection{Effect of Temperature}

The percentage $\mathrm{Pb}(\mathrm{II})$ removal decreased with increased temperature for AABS as shown on Figure 6 while BABS and RBS followed a reverse trend. AABS highest percentage removal was at $30^{\circ} \mathrm{C}(82.4 \%)$ and declined with increasing temperature. The reverse in the trend of result obtained for AABS compared with the other two may be due to the fact that at increased temperature, AABS surface for adsorption has acquire the maximum energy for adsorption while RBS and BABS had not. A similar result, in which adsorptive capacity is inversely proportional to temperature was obtained by Paresh et al. [52] using a biosorbent. Lower temperature of $30^{\circ} \mathrm{C}$ also favoured the Biosorption of Lead(II) and Nickel(II) using Pigeon peas hulls waste by Ramana et al. [53].

\subsection{Adsorption Kinetics for Biosorption}

\subsubsection{The Pseudo-First-Order Kinetics Model}

The pseudo-first-order kinetics equation is expressed as Equation (4) according to Lagergren [54]

$$
\ln \left(q_{e}-q_{t}\right)=q_{e}-k_{1} t
$$

where $q_{e}$ and $q_{t}$ are the adsorption capacities at equilibrium (mg/g) and time $t$, respectively. $K_{1}$ is the rate constant for Pseudo-first-order adsorption $\left(\mathrm{min}^{-1}\right)$. Plots of $\ln \left(q_{e}-q_{t}\right)$ against $t$ at various temperatures resulted in linear graphs with negative slopes $k_{1}$ and $q_{e}$ values were calculated as intercepts. All the values as well as their correlation coefficient $\left(R^{2}\right)$ are as shown on Table 3 for biosorbents. Though values of $R^{2}$ were high but high SSE and the various disparity between the values of $q_{e \text { cal }}$ and $q_{\text {exp. }}$ is an indication that the biosorption of $\mathrm{Pb}(\mathrm{II})$ unto AABS, BABS and RBS do not follow the pseudo-first-order kinetics.

\subsubsection{The Pseudo-Second-Order Kinetics Model}

The pseudo-second-order kinetics equation is expressed as Equation (5) according to Ho and Mckay [55]

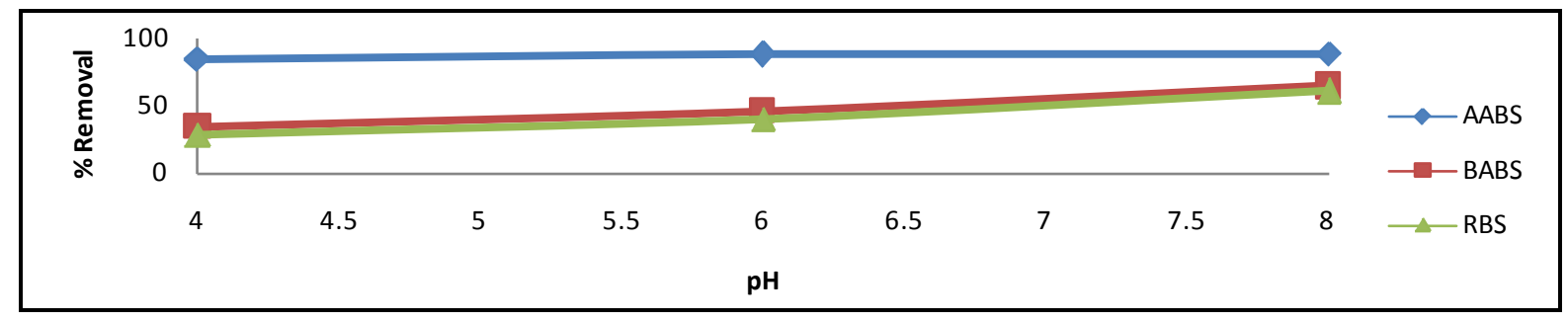

Figure 5. Effect of pH on the percentage removal of Lead(II) using biosorbents.

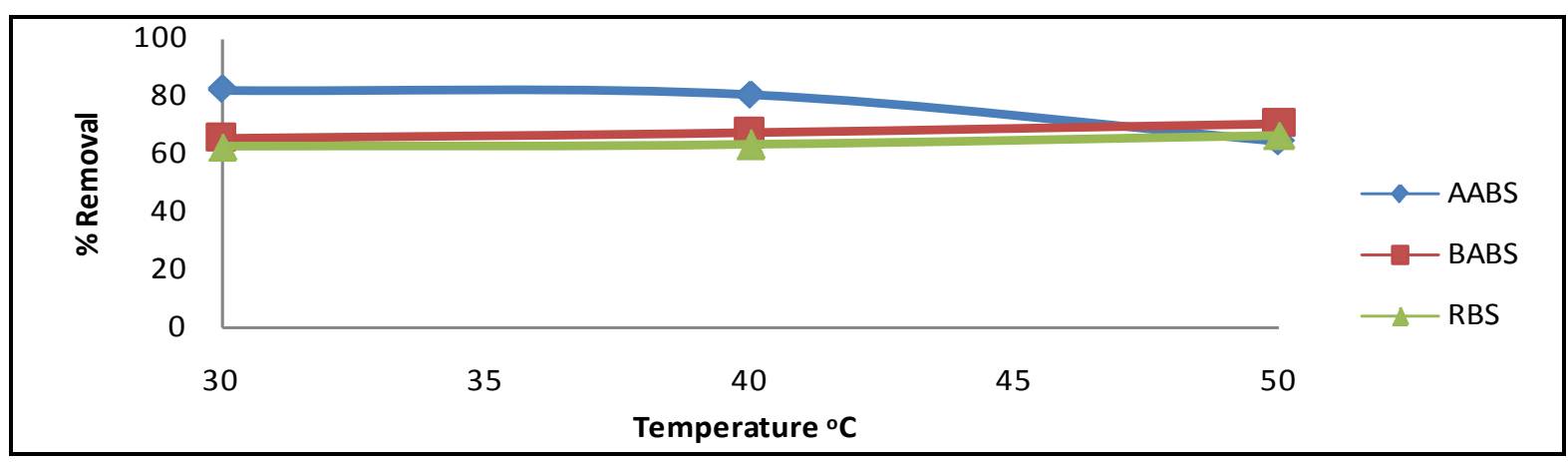

Figure 6. Effect of temperature on the percentage removal of $\mathrm{Pb}(\mathrm{II})$ using different banana stalk biosorbents. 
Table 3. Pseudo-first-order and pseudo-second-order kinetic parameters and correlation coefficients obtained for the biosorption of $\mathrm{Pb}(\mathrm{II})$.

\begin{tabular}{|c|c|c|c|c|c|c|c|c|c|c|}
\hline \multirow[b]{2}{*}{ Adsorbents } & \multirow[b]{2}{*}{$T\left({ }^{\circ} \mathrm{C}\right)$} & \multirow[b]{2}{*}{$q_{e}(\exp )\left(\mathbf{m g} \cdot L^{-1}\right)$} & \multicolumn{4}{|c|}{ Pseudo-first-order } & \multicolumn{4}{|c|}{ Pseudo-second-order } \\
\hline & & & $k_{1}\left(\min ^{-1}\right)$ & $q_{e}(\mathrm{cal})\left(\mathrm{mg} \cdot \mathrm{L}^{-1}\right)$ & $R^{2}$ & SSE & $k_{2}\left(g \cdot \mathrm{mg}^{-1} \cdot \min ^{-1}\right)$ & $q_{e}(\mathrm{cal})\left(\mathrm{mg} \cdot \mathrm{L}^{-1}\right)$ & $R^{2}$ & SSE \\
\hline \multirow[t]{3}{*}{ AABS } & 30 & 9.967 & 0.0091 & 7.184 & 0.969 & 1.14 & 0.0013 & 9.950 & 0.999 & 0.01 \\
\hline & 40 & 9.338 & 0.0105 & 11.413 & 0.855 & 0.85 & 0.0011 & 10.468 & 0.992 & 0.46 \\
\hline & 50 & 9.232 & 0.0114 & 2.436 & 0.684 & 2.77 & 0.0010 & 10.136 & 0.983 & 0.36 \\
\hline \multirow[t]{3}{*}{ BABS } & 30 & 3.756 & 0.0056 & 8.602 & 0.864 & 1.98 & 0.0489 & 2.749 & 1.000 & 0.41 \\
\hline & 40 & 8.042 & 0.0059 & 6.181 & 0.884 & 0.76 & 0.0261 & 8.117 & 0.999 & 0.03 \\
\hline & 50 & 8.052 & 0.0091 & 8.355 & 0.932 & 0.10 & 0.0067 & 8.389 & 0.997 & 0.10 \\
\hline \multirow[t]{3}{*}{ RBS } & 30 & 8.968 & 0.0069 & 8.737 & 0.887 & 0.08 & 0.0012 & 10.460 & 0.968 & 0.60 \\
\hline & 40 & 9.011 & 0.0056 & 7.448 & 0.862 & 0.64 & 0.0066 & 9.259 & 0.998 & 0.10 \\
\hline & 50 & 2.352 & 0.0118 & 1.553 & 0.841 & 0.33 & 0.0010 & 4.730 & 0.957 & 0.96 \\
\hline
\end{tabular}

$$
\frac{\mathrm{d} q_{t}}{\mathrm{~d} t}=k_{2}\left(q_{e}-q_{t}\right)^{2}
$$

where $k_{2}$ is the rate constant of pseudo-second-order adsorption $\left(\mathrm{g} \cdot \mathrm{mg}^{-1} \cdot \mathrm{min}^{-1}\right)$. For the boundary conditions $t=0$ to $t=t$ and $q_{e}=q_{t}$ the integrated form of the equation becomes

$$
\frac{1}{q_{e}-q_{t}}=\frac{1}{q_{e}}+k_{2} t
$$

Rearranging this equation, we have a linear form:

$$
\frac{t}{q_{t}}=\frac{1}{k_{2} q_{e}^{2}}+\frac{1}{q_{e}} t
$$

A plot of $t / q$ versus $t$ was made and $q_{e}$ and $k_{2}$ value was estimated from the slopes and intercepts of the plot. The Sum of Error Square (SSE\%) was also used to evaluate the difference between the $q_{e(\exp )}$ and $q_{e(\mathrm{cal})}$, giving as

$$
\mathrm{SSE}=\frac{\sqrt{\sum\left(q_{\exp }-q_{\mathrm{cal}}\right)^{2}}}{N}
$$

where, $N$ is the number of experiments.

The $R^{2}$ values were as high as 0.99 and the sum of square error was lower when compared to that of pseudo-first-order as there was good agreement between the $q_{e \text { cal }}$ and $q_{\exp }$. of the pseudo-second-order kinetics as shown on Table 3. Therefore the biosorption of Pb(II) onto AABS,BABS and RBS follows a pseudo-secondorder kinetics.

\subsection{Adsorption Isotherms AABS}

\subsubsection{Langmuir Isotherm Model}

Langmuir isotherm is based on the monolayer sorption of $\mathrm{Pb}(\mathrm{II})$ on the surface of carbon sites and is represented linearly by the following equation [56]:

$$
\frac{C_{e}}{q_{e}}=\frac{1}{q_{o} K_{L}}+\frac{C_{e}}{q_{o}}
$$


where $C_{e}(\mathrm{mg} / \mathrm{L})$ and $q_{e}(\mathrm{mg} / \mathrm{g})$ are the concentration of $\mathrm{Pb}(\mathrm{II})$ solution $(\mathrm{mg} / \mathrm{L})$ and the amount of adsorbed lead at equilibrium, respectively, $q_{\max }$ or $q_{o}$ and $K_{L}$ are Langmuir constants related to sorption capacity ( $\mathrm{mg} / \mathrm{g})$ and the energy of sorption $(\mathrm{L} / \mathrm{mg})$ respectively.

The essential characteristics of the Langmuir isotherm can be expressed in terms of a dimensionless equilibrium parameter $R_{L}$ which confirms the favourability of the adsorption process. Given as,

$$
R_{L}=\frac{1}{1+b C_{o}}
$$

where $b$ is the Langmuir constant and $C_{o}$ is the highest $\mathrm{Pb}(\mathrm{II})$ concentration $(\mathrm{mg} / \mathrm{L})$.

The value of $R_{L}$ indicates the type of the isotherm to be either unfavourable $\left(R_{L}>1\right)$, linear $\left(R_{L}=1\right)$, favourable $\left(0<R_{L}<1\right)$ or irreversible $\left(0<R_{L}<1\right)$. The values of $R_{L}$ reported in Table 4 obtained at various temperatures were $<1$, indicating that the adsorption of $\mathrm{Pb}$ (II) onto AABS is favourable. The value of $q_{o}$ obtained was compared with those of other adsorbents used for $\mathrm{Pb}(\mathrm{II})$ removal from aqueous solution and the present study gave the best as shown on Table 5 .

\subsubsection{Freundlich Isotherm Model}

Freundlich isotherm describes the heterogeneous surface energies by multilayer sorption and is expressed by the following equation [57]:

$$
q_{e}=K_{F} C_{e}^{1 / n}
$$

\begin{tabular}{|c|c|c|c|}
\hline & \multicolumn{3}{|c|}{ Temperature (K) } \\
\hline Models & 303 & 318 & 333 \\
\hline \multicolumn{4}{|l|}{ Langmuir isotherm } \\
\hline$Q_{o} \quad\left(\mathrm{mg} \cdot \mathrm{g}^{-1}\right)$ & 13.53 & 16.50 & 18.12 \\
\hline$K_{L} \quad\left(\mathrm{~L} \cdot \mathrm{mg}^{-1}\right)$ & 0.083 & 0.49 & 1.08 \\
\hline$R^{2}$ & 0.98 & 0.99 & 0.99 \\
\hline$R_{L}$ & 0.099 & 0.095 & 0.090 \\
\hline \multicolumn{4}{|l|}{ Freudlich isotherm } \\
\hline$K_{f}$ & 1.49 & 1.04 & 0.62 \\
\hline$N$ & 1.69 & 1.44 & 1.66 \\
\hline$R^{2}$ & 0.99 & 0.99 & 0.90 \\
\hline \multicolumn{4}{|l|}{ Temkin isotherm } \\
\hline$B$ & 2.74 & 3.16 & 2.04 \\
\hline$A$ & 1.04 & 0.63 & 0.40 \\
\hline$B$ & 0.92 & 0.82 & 1.32 \\
\hline$R^{2}$ & 0.96 & 0.97 & 0.86 \\
\hline \multicolumn{4}{|l|}{ D-R isotherm } \\
\hline$Q_{o}\left(\mathrm{mg} \cdot \mathrm{g}^{-1}\right)$ & 6.85 & 42.20 & 5.16 \\
\hline$\beta\left(\mathrm{mol}^{2} \cdot \mathrm{J}^{-2}\right) \times 10^{-6}$ & 0.80 & 0.24 & 6.01 \\
\hline$R^{2}$ & 0.79 & 0.91 & 0.83 \\
\hline$E\left(\mathrm{~kJ} \cdot \mathrm{mol}^{-1}\right)$ & 0.79 & 1.58 & 0.28 \\
\hline
\end{tabular}

Table 4. Comparison of the Isotherms for the adsorption of lead onto AABS at different temperatures. 
Table 5. Comparison of adsorption capacities of various adsorbents for $\mathrm{Pb}(\mathrm{II})$.

\begin{tabular}{ccc}
\hline Adsorbent & Adsorptive capacity $\left(Q_{o} \quad\right.$ in $\left.\mathrm{mg} \cdot \mathrm{g}^{-1}\right)$ & Reference \\
\hline Saracaindica leaf powder & 1.19 & Goyal et al. [60] \\
Bentolite & 7.56 & Mishra and Patel [61] \\
Activated carbon & 6.68 & Mishra and Patel [61] \\
Fly ash & 4.98 & Mishra and Patel [61] \\
Kaolin & 4.50 & Mishra and Patel [61] \\
Banana stalk & 13.53 & This study \\
\hline
\end{tabular}

Linearised as,

$$
\log q_{e}=\log K_{F}+\frac{1}{n} \log C_{e}
$$

where $K_{F}$ and $n$ are the Freundlich constants incorporating the factors affecting the adsorption capacity and the degree of non-linearity between the solute concentration in the solution and the amount adsorbed at equilibrium respectively. Plots of $\log q_{e}$ versus $\log C_{e}$ gave linear graphs with high to $R^{2}$. Comparing the $R^{2}$ values of the two isotherms (Table 4), the adsorption fits the Langmuir model better. Value of $n>1$ indicates that the adsorption is favourable.

\subsubsection{Temkin Isotherm Model}

Temkin isotherm based on the ions sorption heat, which is due to the sorbate and adsorbent interactions, is given by Temkin and Pyzhev [58]

$$
q_{e}=B \ln A+B \ln C_{e}
$$

where:

$$
B=\frac{R T}{b}
$$

where $C_{e}$ is the concentration of sorbate at equilibrium $\left(\mathrm{mg} \cdot \mathrm{L}^{-1}\right), q_{e}$ is the quantity of sorbate bioadsorbed at equilibrium $\left(\mathrm{mg} \cdot \mathrm{g}^{-1}\right), A$ is the equilibrium binding constant $(\mathrm{L} / \mathrm{mol})$ corresponding to the maximum binding energy and constant $B$ is related to the heat of sorption. $T$ is the temperature $(K)$, and $R$ is the ideal gas constant $\left(8.314 \times 10^{-3} \mathrm{~kJ} \cdot \mathrm{mol}^{-1} \cdot \mathrm{K}^{-1}\right)$. The values of $A, B$ and $b$ are given in Table 4 , the lower value of $b$ being $1.32 \mathrm{~kJ} \cdot \mathrm{mol}^{-1}\left(<8 \mathrm{~kJ} \cdot \mathrm{mol}^{-1}\right)$ indicates that the interaction between lead ions and AABS can be expressed as a physisorption process.

\subsubsection{Dubinin-Radushkevich Isotherm (D-R) Model}

The Dubinin-Radushkevich (D-R) model was used to estimate the characteristic porosity of the AABS and the apparent energy of adsorption. The non-linear form of the D-R isotherm equation is given in Equation (16) according to Dubinin-Rasdushkevich [59]:

$$
q_{e}=q_{o} \mathrm{e}^{-\beta \varepsilon^{2}}
$$

The equation is linearised by taking the logarithm on both sides of equation and is expressed as,

$$
\ln q_{e}=\ln q_{o}-\beta \varepsilon^{2}
$$

where $q_{e}$ is the heavy metal amount that is adsorbed per unit mass of AABS in $\mathrm{mg} \cdot \mathrm{g}^{-1} ; q_{o}$ is the maximum adsorption capacity in $\mathrm{mg} \cdot \mathrm{g}^{-1} ; \beta$ is the free energy of sorption per mole of the sorbate as it migrates to the surface of AABS from an infinite distance in the solution in $\mathrm{mol}^{2} \cdot \mathrm{kJ}^{-2}$, and $\varepsilon$ is the Polanyi potential. The Polanyi potential $(\varepsilon)$ can be given as: 


$$
\varepsilon=R T \ln \left(1+1 / C_{e}\right)
$$

where $R$ is the gas constant in $\mathrm{kJ} \cdot \mathrm{K}^{-1} \cdot \mathrm{mol}^{-1}$, and $T$ is the absolute temperature in $K$. A plot of $\ln q_{e}$ versus $\varepsilon^{2}$ gave a linear plot (not shown) from which $\beta$ and $q_{o}$ are obtained from the slopes and the intercepts respectively (Table 4). Similarly, the $\beta$ value obtained was then used to estimate the mean free energy of adsorption $E$ which is calculated by,

$$
E=\sqrt{\frac{1}{2 \beta}}
$$

The values of $E$ were found to be in the range $0.29-1.58 \mathrm{~kJ} \cdot \mathrm{mol}^{-1}$ over the range of temperatures used in this study. Because $E<8 \mathrm{~kJ} \cdot \mathrm{mol}^{-1}$, it suggests that the biosorption of lead ion onto AABS is physically controlled.

\subsection{Thermodynamics Studies for AABS}

Thermodynamic parameters; standard free energy $\left(\Delta G^{0}\right)$, standard enthalpy $\left(\Delta H^{0}\right)$ and standard entropy $\left(\Delta S^{0}\right)$ were calculated using the following equation:

$$
\begin{aligned}
\ln K_{L} & =\frac{\Delta S}{R}-\frac{\Delta H^{0}}{R T} \\
\Delta G^{0} & =-R T \ln K_{L}
\end{aligned}
$$

where $K_{L}$ is the Langmuir constant $(\mathrm{L} / \mathrm{mol}), T$ is the temperature in $K$ and $R$ is the gas constant $\left(\mathrm{kJ} \cdot \mathrm{mol}^{-1} \cdot \mathrm{K}^{-1}\right)$. A plot of $\ln K_{L}$ against $1 / T$ gave linear plot from which $\Delta H^{0}$ and $\Delta S^{0}$ values were obtained from the slope and intercept respectively. From the pseudo-second-order rate constant, $k_{2}$ (Table 3), the activation energy $E_{a}$ for the adsorption of $\mathrm{Pb}(\mathrm{II})$ onto AABS could be determined using equation

$$
\ln k_{2}=\ln A-\frac{E_{a}}{R T}
$$

where $k_{2}$ is the biosorption rate constant, $A$ is the Arrhenius constant, $E_{a}$ is the activation energy $\left(\mathrm{kJ} \cdot \mathrm{mol}^{-1}\right)$. By plotting $\ln k_{2}$ versus $1 / T, E_{a}$ can be obtained from the slope of the linear plot and is presented in Table 6 . The negative free energy values at various temperature as shown on Table 6 indicates that the adsorption of $\mathrm{Pb}$ (II) unto AABS is spontaneous and thermodynamically favoured. In addition, the range of values between 0 to $-20 \mathrm{~kJ} \cdot \mathrm{mol}^{-1}$ further confirms that the adsorption process is a physisorption process. The positive value of $\Delta H^{0}$ obtained shows that the process is endothermic in nature and it range of values $\left(2.1-20.9 \mathrm{~kJ} \cdot \mathrm{mol}^{-1}\right) \mathrm{im}-$ plies that the process is physically controlled. The values of $\Delta S^{0}$ is positive indicating that there was randomness at the solid-liquid interface during the adsorption of the $\mathrm{Pb}(\mathrm{II})$ onto AABS.

\section{Conclusion}

The biosorption experiment carried out using banana stalk (Musa paradisiaca) was found suitable for the adsorption of $\mathrm{Pb}(\mathrm{II})$. Considering the three modified banana stalk (AABS, BABS and RBS) used in this study, AABS was established to be the best adsorbent of $\mathrm{Pb}(\mathrm{II})$ with $96.76 \%$ metal removal. The operational parameter (Adsorbent dose, temperature, initial metal ion concentration, time and $\mathrm{pH}$ ) had varied effects on the percentage $\mathrm{Pb}$ (II) removal. It was found out that Pseudo-second order kinetic model was suitable for the adsorption of

Table 6. Thermodynamic parameters for the biosorption of Pb(II) by AABS.

\begin{tabular}{ccccc}
\hline$T\left({ }^{\circ} \mathrm{C}\right)$ & $\Delta G^{0}\left(\mathrm{~kJ} \cdot \mathrm{mol}^{-1}\right)$ & $\Delta H^{0}\left(\mathrm{~kJ} \cdot \mathrm{mol}^{-1}\right)$ & $\Delta S^{0}\left(\mathrm{~kJ} \cdot \mathrm{mol}^{-1}\right)$ & $E_{a}\left(\mathrm{~kJ} \cdot \mathrm{mol}^{-1}\right)$ \\
\hline 30 & -18.75 & 12.63 & 0.049 & 4.365 \\
40 & -24.02 & & & \\
50 & -26.00 & & & \\
\hline
\end{tabular}


$\mathrm{Pb}(\mathrm{II})$. Four adsorption Isotherms (Langmuir, Freudlich, Temkin and Dubinin-Radushkevich) were tested and confirmed suitable to describe the nature of the adsorption process of $\mathrm{Pb}(\mathrm{II})$ removal from aqueous solution, but Langmuir Isotherm was the best. The thermodynamics studies showed that $\Delta G^{0}$ values were negative indicating that the process of $\mathrm{Pb}(\mathrm{II})$ adsorption onto AABS was spontaneous and the positive $\Delta H^{0}$ and $\Delta S^{0}$ suggests that the biosorption process is an endothermic reaction.

\section{Acknowledgements}

The authors acknowledge the support given by Dr. O. S. Bello of Department of Pure and Applied Chemistry, Ladoke Akintola University of Technology, Ogbomoso-Nigeria in making some laboratory facilities available for this work from his Third World Academy of Science (TWAS) Research Grant (Grant number: 11-249 RG/CHE/AF/AC_1_UNESCO FR: 3240262674).

\section{References}

[1] Ko, D.C.K., Porter, J.F. and Mckay, G. (2000) Optimized Correlation for the Fixed Bed Adsorption of Metal Ions on Bone Char. Chemical Engineering Science, 55, 5819-5829. http://dx.doi.org/10.1016/S0009-2509(00)00416-4

[2] Koller, K.B.T., Spurgeon, A. and Levy, L. (2004) Recent Development in Low Level Exposure and Intellectual Impairment in Children. Environmental Health Perspective, 112, 987-994. http://dx.doi.org/10.1289/ehp.6941

[3] National Research Council Canada (1978) Effect of Lead in the Canadian Environment, Report NRCC 16745, Ottawa.

[4] Patterson, J.W. (1985) Industrial Wastewater Treatment Technology. 2nd Edition, Butterworth Publishers, Stoneham.

[5] Axtell, N.R., Sternberg, S.P.K. and Claussen, K. (2003) Lead and Nickel Removal Using Microspora and Lemna Minor. Bioresource Technology, 89, 41-48. http://dx.doi.org/10.1016/S0960-8524(03)00034-8

[6] Bhatti, H.N., Mumtaz, B., Hanif, M.A. and Nadeem, R. (2007) Removal of Zinc Ions from Aqueous Solution Using Moringa oleifera Lam. (Horseradish Tree) Biomass. Process Biochemistry, 42, 547-553. http://dx.doi.org/10.1016/j.procbio.2006.10.009

[7] Qiu, Y., Cheng, H., Xu, C. and Sheng, S.D. (2008) Surface Characteristics of Crop-Residue-Derived Black Carbon and Lead(II) Adsorption. Water Resource, 42, 567-574.

[8] Needleman, H.L. (1999) History of Lead Poisoning in the World. In: George, A.M., Ed., Lead Poisoning Prevention and Treatment: Implementing a National Program in Developing Countries, The George Foundation, Bangalore, 17-25.

[9] Pruss-Ustun, A., Fewtrell, L., Landrigan, P.J. and Ayuso-Mateos, J.L. (2004) Lead Exposure. In: Ezzati, M., Lopez, A.D., Rodgers, A. and Murray, C.J.L., Eds., Comparative Quantification of Health Risks: Global and Regional Burden of Disease Attributable to Selected Major Risk Factors, World Health Organization, Geneva, 1495-1542.

[10] Tong, S., Yasmin, E., Von, S. and Prapamontol, T. (2000) Environmental Lead Exposure: A Public Health Problem of Global Dimensions. Bulletin of the World Health Organisation, 78, 1068-1077.

[11] Wang, J.L. (2000) Immobilization Techniques for Biocatalysts and Water Pollution Control. Science Press, Beijing.

[12] dos Santos, W.N.L., Cavalcante, D.D., da Silva, E.G.P., da Virgrens, C.F. and Dias, F.D. (2011) Biosorption of Pb(II) and Cd(II) Ions by Agave sisalana (Sisal Fibre). Microchemical Journal, 97, 269-273. http://dx.doi.org/10.1016/j.microc.2010.09.014

[13] Ademorati, C.M.A. (1996) Environmental Chemistry and Toxicology. Foludex Press Ltd., Ibadan.

[14] Schumann, K. (1990) The Toxicological Estimation of the Heavy Metal Content (Cd, Hg, Pb) in Food for Infants and Small Children. Zeitschrift für Ernährungswissenschaft, 29, 54-73.

[15] Kazi, T.G., Jalbani, N., Kazi, N., Jamali, M.K., Arain, M.B., Afridi, H.I., Kandhro, A. and Pirzado, Z. (2008) Evaluation of Toxic Metals in Blood and Urine Samples of Chronic Renal Failure Patients, before and after Dialysis. Renal Failure, 30, 737-745. http://dx.doi.org/10.1080/08860220802212999

[16] Hinchee, R.E. and Alleman, B.C. (1991) Hydrocarbon Bioremediation. CRC Press, Boca Raton.

[17] Chen, H., Zhao, J., Dai, G.L., Wu, J.Y. and Yan, H. (2010) Adsorption Characteristics of Pb(II) from Aqueous Solution onto Natural Biosorbent, Fallen Cinnamomum camphora Leaves. Desalination, 262, 174-182. http://dx.doi.org/10.1016/j.desal.2010.06.006

[18] Agarry, S.E., Ogunleye, O.O. and Aworanti, A.O. (2013) Biosorption Equilibrium, Kinetic and Thermodynamic Modeling of Naphthalene Removal from Aqeous Solution onto Modified Spent Tea Leaves. Environmental Technology, 34, 825-839. http://dx.doi.org/10.1080/09593330.2012.720616

[19] Ozcan, A. and Ozcan, A.S. (2005) Adsorption of Acid Red 57 from Aqueous Solutions onto Surfactant Modified Sepi- 
olite. Journal of Hazardous Materials, 125, 252 -259. http://dx.doi.org/10.1016/j.jhazmat.2005.05.039

[20] Baig, T.H., Garcia, A.E., Tiemann, K.J. and Gardea-Torresdey, J.L. (1999) Adsorption of Heavy Metal Ions by the Biomass of Solanum elaeagnifolium (Silver Leaf Nightshade). Proceedings of 14th Conference of Hazardous Waste Research, St. Louis, 24-27 May 1999, 132-142.

[21] Babarinde, N.A.A., Babalola, J.O. and Sanni, R.A. (2006) Biosorption of Lad Ions from Aqueous Solution by Maize Leaf. International Journal of Physical Sciences, 1, 23-26.

[22] Demirbas, A. (2008) Heavy Metal Adsorption onto Agro-Based Waste Materials: A Review. Journal of Hazardous Materials, 157, 220-229. http:// dx.doi.org/10.1016/j.jhazmat.2008.01.024

[23] Ajmal, M., Rao, R.A.K., Ahmad, R. and Ahmad, J. (2002) Adsorption Studies on Citrus reticulate (Fruit Peel of Orange): Removal and Recovery of Ni (II) from Electroplating Wastewater. Journal of Hazardous Materials, 79, 117131. http://dx.doi.org/10.1016/S0304-3894(00)00234-X.

[24] Hassanein, T.F. and Koumanova, B. (2012) Binary Mixture Sorption of Basic Dyes onto Wheat Straw. Bulgarian Chemical Communication, 44, 131-138.

[25] Hassanein, T.F. and Koumanova, B. (2012) Removal of Mercury, Lead and Copper from Aqueous Solution by Activated Carbon of Palm Oil Empty Fruit Bunch. World Applied Science Journal, 5, 84-91.

[26] Oboh, O.I. and Aluyor, E.O. (2008) The Removal of Heavy Metal Ions from Aqueous Solution Using Sour Sop Seeds as Biosorbent. African Journal of Biotechnology, 7, 4508-4511.

[27] Egila, J.N. and Okorie, E.O. (2002) Influence of pH on the Adsorption of Trace Metals on Ecological and Agricultural Adsorbents. Journal of Chemical Society of Nigeria, 27, 95-98.

[28] Gimba, C.E., Olayemi, J.Y., Ifijeh, D.O.H. and Kagbu, J.A. (2001) Adsorption of Dyes by Powdered and Granulated Activated Carbon from Coconut Shell. Journal of Chemical Society of Nigeria, 26, 23-27.

[29] Upatham, E.S., Boonya, B., Kriatracjie, M., Pokethitiyook, P. and Park, K. (2002) Biosorptionof Cadmium and Chromium in Duck weed Wolffia globosa. International Journal of Phytoremediation, 4, 73-86. http://dx.doi.org/10.1080/15226510208500074

[30] Abdel-Ghani, N.T., Hefny, M. and El-Chaghaby, G.A.F. (2007) Removal of Lead from Aqueous Solution Using Low-Cost Abundantly Available Adsorbents. International Journal of Environmental Science and Technology, 4, 6773. http://dx.doi.org/10.1007/BF03325963

[31] Ho, Y.S., Huang, C.T. and Huang, H.W. (2002) Agricultural By-Products as a Metal Sorbent: Sorption of Copper Ions from Aqueous Solution onto Tree Fern. Process Biochemistry, 37, 1421-1430. http://dx.doi.org/10.1016/S0032-9592(02)00036-5

[32] Egila, J.N., Dauda, B.E.N., Iyaka, Y.A. and Jimoh, T. (2011) Agricultural Waste as a Low Cost Adsorbent for Heavy Metal Removal from Wastewater. International Journal of Physical Sciences, 6, 2152-2157.

[33] Bello, O.S. and Ahmad, M.A. (2011) Adsorptive Removal of a Synthetic Textile Dye Using Cocoa Pod Husks. Toxicological and Environmental Chemistry, 93, 1298-1308. http://dx.doi.org/10.1080/02772248.2011.590490

[34] Gardea-Torresdey, J., Hejazi, M., Tiemann, K., Parsons, J.G., Duarte-Gardea, M. and Henning, J. (2002) Use of Hop (Humulus lupulus) Agricultural By-Products for the Reduction of Aqueous Lead(II) Environmental Health Hazards. Journal of Hazardous Materials, 91, 95-112. http://dx.doi.org/10.1016/S0304-3894(01)00363-6

[35] Li, X., Tang, Y., Xuan, Z., Liu, Y. and Luo, F. (2007) Study on the Preparation of Orange Peel Cellulose Adsorbents and Biosorption of $\mathrm{Cd}^{2+}$ from Aqueous Solution. Separation and Purification Technology, 55, 69-75. http://dx.doi.org/10.1016/j.seppur.2006.10.025

[36] Liang, S., Guo, X., Feng, N. and Tian, Q. (2009) Application of Orange Peel Xanthate for the Adsorption of Pb ${ }^{2+}$ from Aqueous Solutions. Journal of Hazardous Materials, 170, 425-429. http://dx.doi.org/10.1016/j.jhazmat.2009.04.078

[37] Liang, S., Guo, X., Feng, N. and Tian, Q. (2009) Adsorption of $\mathrm{Cu}^{2+}$ and $\mathrm{Cd}^{2+}$ from Aqueous Solution by Mercapto-Acetic Acid Modified Orange Peel. Colloids and Surfaces B, 73, 10-14. http://dx.doi.org/10.1016/j.colsurfb.2009.04.021

[38] Amir, H.M., Darush, N., Forugh, V. and Sharokh, N. (2005) Tea Waste as an Adsorbent for Heavy Metal Removal from Industrial Wastewaters. American Journal of Applied Science, 2, 372-375. http://dx.doi.org/10.3844/ajassp.2005.372.375

[39] Medeios, R.G., Scoffner, M.L.A.P., Thome, J.A., Cacais, A.O.G., Estelles, R.S., Salles, B.C., Ferreira, H.M., LucenaNeto, S.A., Silva Jr., F.G. and Filho, E.X.F. (2000) The Production of Hemicelluloses by Aerobic Fungi on Medium Containing Residue of Banana Plants as Substrate. Biotechnology Progress, 16, 522-524. http://dx.doi.org/10.1021/bp0000398

[40] Bello, O.S., Ahmad, M.A. and Ahmad, N. (2012) Adsorptive Features of Banana (Musa paradisiaca) Stalk-Based Activated Carbon for Malachite Green Dye Removal. Chemistry and Ecology, 28, 153-167. 
http://dx.doi.org/10.1080/02757540.2011.628318

[41] Volesky, B. (1990) Biosorption and Biosorbents. In: Biosorption of Heavy Metals, CRC Press, Boca Raton, 3-5.

[42] Volesky, B. (1990) Removal and Recovery of Heavy Metals. In: Biosorption of Heavy Metals, CRC Press, Boca Raton, 36.

[43] Volesky, B. (1994) Advances in Biosorption of Metals: Selection of Biomass Types. FEMS Microbiology Review, 14, 291-302. http://dx.doi.org/10.1111/j.1574-6976.1994.tb00102.x

[44] Niu, H., Shu, X., Wang, J.H. and Volesky, B. (1993) Removal of Lead from Aqueous Solutions by Penicillium. Biotechnology and Bioengineering, 42, 785-787. http://dx.doi.org/10.1002/bit.260420615

[45] Puranik, P.R. and Paknikar, K.M. (1999) Influence of Co Cations on Biosorption of Lead and Zinc: A Comparative Evaluation in Binary and Multimetal Systems. Bioresources Technology, 70, 269-276. http://dx.doi.org/10.1016/S0960-8524(99)00037-1

[46] Oo, C.W., Kassim, M.J. and Pizzi, A. (2009) Characterization and Performance of Rhizophora apiculata Mangrove Polyflavonoid Tannins in the Adsorption of Copper(II) and Lead(II). Industrial Crops and Products, 30, 152-161. http://dx.doi.org/10.1016/j.indcrop.2009.03.002

[47] Li, X., Zheng, W., Wang, D., Yang, Q., Cao, J., Yue, X., Shen, T. and Zeng, G. (2010) Removal of Pb(II) from Aqueous Solutions by Adsorption onto Modified Areca Waste: Kinetics and Thermodynamics Study. Desalination Journal, 258, 148-153.

[48] Njoku, V.O., Oguzie, E.E., Obi, C., Bello, O.S. and Ayuk, A.A. (2011) Adsorption of Copper(II) and Lead(II) from Aqueous Solutions onto a Nigerian Natural Clay. Australian Journal of Basic and Applied Sciences, 5, 346-353.

[49] Dermibas, E., Kobya, M., Senturk, E. and Ozkan, T. (2004) Adsorption Kinetics for the Removal of Cr(VI) from Aqueous Solutions on the Activated Carbon Prepared from Agricultural Wastes. Water SA, 30, 533-539.

[50] Adeogun, A.I., Bello, O.S. and Adeboye, M.D. (2010) Biosorption of Lead Ions on Biosorbent Prepared from Plumb Shells (Spondias mombin): Kinetics and Equilibrium Studies. Pakistan Journal of Scientific and Industrial Research, 53, 246-251.

[51] Puranik, P.R. and Paknikar, K.M. (1997) Biosorption of Lead and Zinc from Solutions using Streptoverticillium cinnamoneum Waste Biomass. Journal of Biotechnology, 55, 113-124. http://dx.doi.org/10.1016/S0168-1656(97)00067-9

[52] Paresh, C., Sarma, N.S. and Serma, H.P. (2010) Removal of Lead(II) from Aqueous Solution using Heartwood of Areca Catechu Powder. Desalination, 256, 16-21. http://dx.doi.org/10.1016/j.desal.2010.02.029.

[53] Ramana, D.K.V., Reddy, H.H.K., Yu, J.S. and Seshaiah, K. (2012) Pigeon Peas Hulls Waste as Potential Adsorbent for Removal of $\mathrm{Pb}(\mathrm{II})$ and $\mathrm{Ni}(\mathrm{II})$ from Water. Chemical Engineering Journal, 197, 24-33. http://dx.doi.org/10.1016/j.cej.2012.04.105

[54] Lagergren, S. (1898) Zur Theorie der Sogenannten Adsorption gel Ster Stoffe, Kungliga Svenska Vetenskapsakademiens. Handlingar, 24, 1-39.

[55] Ho, Y.S. and Mckay, G. (1999) Pseudo-Second Order Model for Sorption Processes. Process Biochemistry, 34, 451465. http://dx.doi.org/10.1016/S0032-9592(98)00112-5

[56] Langmuir, I. (1918) The Adsorption of Gases on Plane Surfaces of Glass, Mica and Platinum. Journal of American Chemical Society, 40, 1361-1368. http://dx.doi.org/10.1021/ja02242a004

[57] Freundlich, H.M.F. (1906) Over the Adsorption in Solution. Zeitschrift fur Physikalische Chemie, 57, 385-470.

[58] Temkin, M. and Pyzhev, V. (1939) Kinetics of Ammonia Synthesis on Promoted Iron Catalysts. Journal of Physical Chemistry, 13, 851-857.

[59] Dubinin, M.M. and Radushkevich, L.V. (1947) Equation of the Characteristic Curve of Activated Carbon. Proceedings of the National Academy of Sciences of the United States of America, 55, 331-333.

[60] Goyal, P., Sharma, P., Srivastava, S. and Srivastava, M.M. (2008) Saraca indica Leaf Powder for Decontamination of Pb: Removal, Recovery, Adsorbent Characterization and Equilibrium Modelling. International Journal of Environmental Science and Technology, 5, 27-34. http://dx.doi.org/10.1007/BF03325994

[61] Mishra, P.C. and Patel, R.K. (2009) Removal of Lead and Zinc Ions from Water by Low Cost Adsorbents. Journal of Hazardous Materials, 168, 319-325. http://dx.doi.org/10.1016/j.jhazmat.2009.02.026 
Scientific Research Publishing (SCIRP) is one of the largest Open Access journal publishers. It is currently publishing more than 200 open access, online, peer-reviewed journals covering a wide range of academic disciplines. SCIRP serves the worldwide academic communities and contributes to the progress and application of science with its publication.

Other selected journals from SCIRP are listed as below. Submit your manuscript to us via either submit@scirp.org or Online Submission Portal.
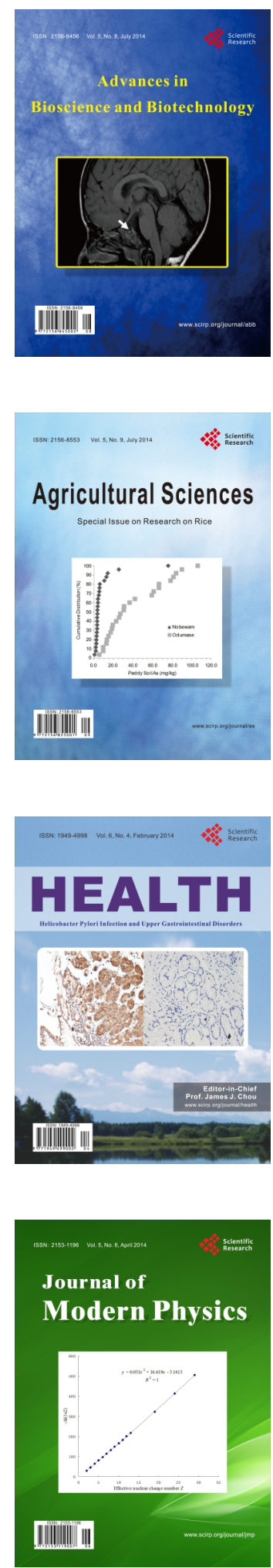
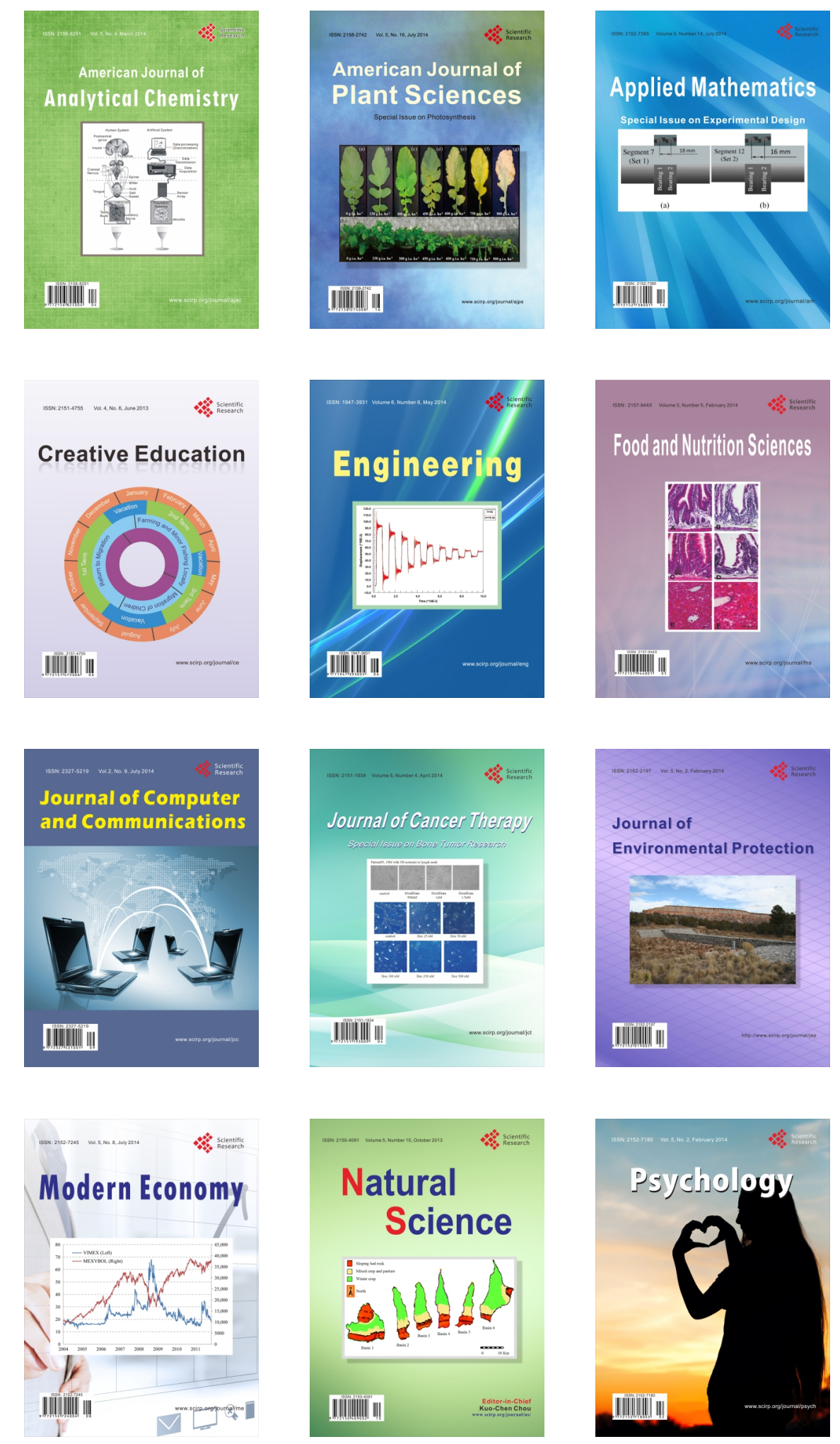